\title{
Grosse Executorial Strength What Is Recognition of Debt in Practice (Study in Class 1A of Mataram District Court)
}

\author{
Ikang Satrya Medyantara; Lalu Husni; Sudiarto \\ Master of Notary, University of Mataram, Indonesia
}

http://dx.doi.org/10.18415/ijmmu.v6i3.886

\begin{abstract}
The purpose of this study was to analyze the strength of executorial Grosse Debt Recognition Deed in practice in the Class 1A of Mataram District Court. The research method used is empirical normative research. First, based on the results of the research that the Strength of Grosse's Debt Recognition Act in Debt Payment Implementation has a strength that is undoubtedly very strong because it can immediately be submitted for execution without going through a lawsuit in court, which is due to an executive power in the Grosse deed the acknowledgment of Debt in the head of the Deed is that there is an order for justice based on the One and only God made by the Second Notary, Grosse deed of debt recognition can be carried out directly without going through a claim process in court, bearing in mind the Grosse deed of debt recognition provided the head of the office reads for the sake of justice based on the supreme divinity, so that with the power contained in the debt recognition deed, direct execution can be carried out by the creditor to the court if the debtor defaults, without going through the claim process in court. Third, there are several relationships in the execution of Grosse's deed. Debt recognition, for example, the community's knowledge of the gross debt recognition deed. The second, sometimes the notary in making debt recognition Grosse statements does not pay attention to material and formal requirements from the Grosse deed itself.
\end{abstract}

Keywords: Executive Power; Grosse Debt Recognition Deed; In Practice

\section{Introduction}

The 1945 Constitution of the Republic of Indonesia, in Article 1 paragraph (3) states that Indonesia is a legal state, then all consequences of the rule of law are that all forms of legal acts must be based on applicable legal provisions. The state theory of welfare law is a combination of the concepts of state law and welfare state. The rule of law (rechtsstaat) is a state that places the law as the basis of its power and the implementation of such power in all its forms is carried out under the rule of law. Whereas the concept of a welfare state is the state or the government not merely as a guardian of security or public order, but the main bearer of the responsibility to realize social justice, public welfare and the maximum prosperity of the people. The State of Welfare Law was born as a reaction to the failure of the concept of the state of classical liberal law and the state of socialist law (Husni, 2010). 
In essence, every human being in everyday life cannot escape from what is called a necessity, of course with human desires that always want to fulfill all forms of necessity for survival. As a matter of course, every human being will do various ways to fulfill all the needs of each individual -one. Then related to human needs according to Supramono (2013) can be classified into three types, namely: 1) Primary needs are needs that must be prioritized fulfillment every day and humans can not avoid it, such as the need to eat, drink, clothes, bathe (need water, toothbrush, towel), clock (hour), and transport costs. 2) Secondary needs are needs that the level does not have to be fulfilled every day but humans need to fulfill them, including household appliances such as table chairs, beds, refrigerators, televisions, besides saving money, motorbikes, recreation, and so on. 3) Tertiary needs are higher-level needs that tend towards luxury and the costs are also expensive, such as houses, cars, gardens, playgrounds, and fish ponds.

Every human being in an effort to fulfill his survival must work hard and make every effort to earn income to support his family. To earn income, of course, it is done in various ways to cultivate a profession such as entrepreneurship.

The various types of businesses carried out by someone, with the hope of solely earning income, according to Muhammad (2002) type of business are: 1) Business in the economic field, which covers the industrial sector; 2) trade business; 3) service business, and 4) financial business (financing). While business is any action, action, or activity in the economic field, which is carried out by every businessman with the aim of obtaining profits and or profits.

In developing the continuity of a business activity, a person certainly needs large capital. In this case, not everyone has large capital, so it is needed by the party giving the loan, namely the creditor. Creditors can be individuals, as well as credit institutions such as banking, cooperatives, finance, and so on. Muhammad (2002) argues that in terms of the types of creditors, those who can provide debt are classified into two types, namely individuals and companies / banks. Debt debt between individuals is a private matter, because anyone who can give debt to others. In contrast to banks, an institution that forms as a company is one of the functions of providing credit to its customers, which is regulated in Law No. 7 of 1992 concerning Banking as amended by Law No. 10 of 1998.

As a creditor who does not want to be harmed by the debtor, of course he has protected himself by making a grosse deed which is solely aimed at making payments made by the debtor, as well as to strengthen the legality of civil law relations between creditors and debtors. Supramono, (2013) argues that although the contents are in the form of unilateral statements from the debtor, the debt recognition system has a very strong binding power, because if the debtor fails to pay the debt, the debt statement can be used as evidence and at the same time execute debtor debt repayments.

As is known, said the grosse deed in Indonesian law is regulated in civil procedure law in Article 224 HIR (Herzien Inlandsch Reglement), Article 258 R.Bg. (Rechtsreglement Buitengewesten). As well as in Article 1 number 11 of Act Number 2 of 2014 concerning Amendments to Law Number 30 of 2004 concerning Notary Position. Article 224 HIR (Herzien inlandsch reglement) what is meant by Grosse deed is a grosse from a mortgage deed and debt letter made before a notary in Indonesia and whose head for justice based on the supreme divinity has the same power as the judge's decision. If not by peaceful means, the letter is executed by order and under the leadership of the head of the district court, in whose jurisdiction the place of residence or residence of the debtor or place of choice is chosen, namely in the manner stated in the previous articles in the section this, but with the understanding that coercion can only be done, if it has been permitted by the judge's decision. If the decision of the judge must be carried out entirely or in part outside the jurisdiction of the district court that ordered the implementation of the decision, the rules of article 195 paragraph (2) and so on must be followed. Article 258 (1) Rbg reads Grosse mortgage deeds and debt securities made by notaries in the territory of Indonesia contain words that sound in the name of the king (now: For the sake of justice based on the Almighty Godhead) have the same power as court decisions (Fikri \& Tanzah, 2010). 
Based on the provisions of Article 224 HIR and 258 paragraph (1) of the Rbg above, there are two things that are regulated, namely regarding mortgage deeds and debt securities, mortgage deeds are debt guarantees against immovable property, but the provisions regarding mortgages are regulated in the second book of the Civil Code was revoked by the presence of Law No. 4 of 1996 concerning Mortgage Rights. Then related to the debt referred to above is a debt acknowledgment in which the debtor acknowledges that he is truly in debt to the creditor. Seeing the provisions of the two Articles above, the mortgage deed and the recognition of debt can only be made in the form of a grosse deed. What is more stated in Article 1 number 11 of Act Number 2 of 2014 concerning Amendments to Law Number 30 Year 2004 concerning The position of Notary, more specifically regulates the notion of grosse deeds, in which the grosse deed is only interpreted as national acknowledgment, while the sound of the provisions in the Notary position Act are: one copy of the Deed of debt recognition with the head of the Deed "For Justice Based on Divinity The One Who "has executorial power. Observing the provisions of the Act on notary positions above, only the recognition of debt is made in the form of a grosse deed.

Letter of acknowledgment of debt is one form of grosse deed, concerning legal actions in the form of a statement of debt recognition from the debtor. In line with its name, namely debt recognition, only one party makes the letter. The party in question is the party who borrows money, namely the debtor. In a debt statement, the debtor principally acknowledges that he has owed a sum of money to the creditor. The letter of debt recognition is not made by the creditor and debtor, because this letter is not a new agreement. The debt agreement as a principal, is made only once and still applies to them. Even though the debtor makes a debt acknowledgment, it does not result in the debt agreement being deleted (Supranomo, 2013).

The Grosse debt recognition deed certainly regulates the statement of the debtor regarding obligations that must be fulfilled as a form of achievement to the creditor or the party who owes. When one party defaults on a principal agreement, a right arises, for example not fulfilling the debt at all, fulfilling a part, and late fulfilling these criteria can be said to have committed a violation of the clauses in the Grosse deed, when that happens, the creditor both banking institutions and individuals who are creditors on the basis of Grosse Deed who have the right "For the sake of Justice Based on the One Godhead" and the executorial power which means that the deed has the same strength as the court decision which has a permanent power. With the deed, it can submit a request for execution directly to the court.

But in people's lives with a variety of situations and conditions that exist in each individual certainly does not always work as expected. To obtain an object that is desired by each individual, institution or field of mining for payment by using a grosse deed which is intended solely to guarantee the interests of the creditor for civil actions in the field of credit carried out with the creditor.

In principle, a Grosse debt recognition certificate can be carried out directly because it has the irrationality "For the sake of Justice based on the Almighty God" which has executorial power, which means that a grosse deed of debt recognition has the same power as a court decision that has permanent legal force. It will still be in fact not all debt acknowledgments that can be directly executed, there are those that can immediately be executed and some that cannot be directly executed but through a lawsuit process in court, so that these conditions create chaos for creditors who want an execution from the debtor as an interested party. With the claim process, it certainly takes a long time to execute until the decision has a permanent legal force (inkracht van gewijsde) so that it does not provide legal certainty to creditors.

\section{Method}

This study uses empirical normative legal research method is empirical Normative Law research by making field data as a support. According to Mukti \& Yulianto (2010) Normative legal research, is research that includes research on legal principles, research on legal systematics, research on the degree 
of legal synchronization, legal history research, and legal comparison research. Approach through legislation, conceptual and analytical approaches. The sources of legal material in this study are primary, secondary and tertiary legal materials. Legal material collection techniques in this study were carried out through the study of literature on legal material, both primary legal material, secondary legal material, tertiary legal material or non-legal material.

\section{Result and Discussion}

\section{A. Strength of Grosse Debt Recognition Deed in the Implementation of Debt Payments}

The Grosse deed has executive power. What is agreed with the executorial power here is that the execution (auction) can be carried out without first going through a court process and legal force as well as the decision of a court judge with permanent legal force. According to Article $224 \mathrm{HIR}$ as the executive force of the grosse deed only applies to mortgage grosse deeds and advanced approval deeds. Basically, it can only be resolved in a Dispute that begins with a lawsuit, but in some cases the Law determines exceptions to the principle, in the sense that it is meant by matters determined by the Law concerning anything that can be carried out directly such as a Judge's Decision which has permanent legal force. Claimed is Grosse Debt recognition deed (Juhaya, 2011).

The existence of the executive force of the grosse deed will clearly benefit the parties who are litigating, because in the implementation of the method the execution is felt to be very efficient in accordance with the demands of the progress of the times which require everything to run fast and precisely with good results. Grosse debt recognition deed is a deed that contains a statement from the debtor that he owes creditors. One of the strengths of Grosse's debt recognition certificate is that it lies executorial rather than Grosse's debt recognition deed. Article 1 Number 11 of Law Number 2 of 2014 concerning Amendment to Law Number 30 of 2004 concerning Notary Position said that the Grosse deed was one of the copies of the deed for debt recognition, with the head of the deed "For the sake of Justice Based on the One Godhead" Has executive power.

According to Supramono, (2013) there are several things that need to be considered related to Grosse Debt Recognition deeds, namely: 1) Grosse Debt Recognition deeds must be made unilaterally. In line with its name, which is a debt statement, only one party makes the letter. The party in question is the party who borrows money, namely the debtor. In a debt statement, at the same time the debtor acknowledges that he has owed a sum of money to the creditor. 2) Debt Recognition Letter Contains a Statement. As is known, the debt recognition letter is not a debt agreement letter, but the contents are in the form of a statement of the debtor about the recognition of himself who has been owed to the creditor.

As for the statement of the debtor in the debt statement, on the map it contains the following matters: 1) Name of the creditor or the party lending money. 2) Date of recipient of money. 3) The amount of debtor debts. 4) The period or date of debt repayment. 5) Signatures and names of bright debtors.

Although the contents are in the form of unilateral statements from the debtor, however, the debt acknowledgment has a very strong binding power, because if the debtor fails to pay the debt, the debt statement can be used as evidence and simultaneously to execute debtor debt collection.

\section{Debt recognition letters are accessoir}

Between the loan agreement and debt securities have a relationship with each other. The debt recognition letter only exists after the debt agreement. Debt agreements are always made in advance of 
debt instruments. It is impossible to happen, a debt statement is first, after that the debt agreement is made. Basically people claim to have debts after the concerned receives a money loan. Both of these actions do not stand alone, but as an inseparable whole.

As is known, the position of the debt agreement is as a principal agreement. The debt acknowledgment is a unilateral act made after the existence of a debt agreement. The relationship between the two is very tight, because the debt statement cannot be released from the principal agreement. The existence of a debt statement is highly dependent on the principal agreement. Debt recognition letters always follow the debt agreement. If the principal agreement is completed, then the debt statement is also completed. No one is willing to claim to be in debt, if the debt is paid in full.

\section{Debt Recognition Letter is not a necessity}

The creditors and debtors make the agreement on actual accounts payable considered sufficient, because the agreement is binding on both parties, and acts as an Act for them. In the debt agreement generally the rights and obligations of each creditor and debtor have been determined. With these rights, the creditor can claim his rights to the debtor, and conversely the debtor can claim his rights so that the creditor performs his obligations. Actually, between creditors and debtors do not need to sue each other, as long as the agreement can be carried out with good agreement.

The emergence of a debt acknowledgment, can come from the creditor's initiative, or from the debtor's initiative. If it comes from the creditor's initiative, the purpose of making a debt recognition letter is to secure the debt that the debtor can return his debt. As for the arrival of the debtor's initiative, it is no more than just an affirmation of the debtor regarding his debt.

The position of debt securities as a complement to the debt agreement. Debt recognition can function as written evidence, proving that the debtor has a debt to the creditor. In the review of the contents of the letter, which is in the form of recognition of the debtor, that recognition is a proof that has perfect proof power. With the power of perfect proof. With the power of perfect proof, the contents can be trusted by judges and do not require other evidence. In addition, the debt acknowledgment in the form of the Grosse deed, is used as a tool to carry out the execution of debtor debt payments to creditors, by applying for an execution through a district court.

\section{Debt Recognition Letter in the Form of Grosse deed}

In the provisions of Article $224 \mathrm{HIR} /$ Article $258 \mathrm{R} . \mathrm{Bg}$. set, that the debt recognition letter is made before a notary, this shows the letter must be made authentically. A letter made by or in the presence of a notary is called an authentic deed. Therefore, a debt statement is made in the form of an authentic deed as one of the conditions. Then the next requirement in the article is a letter or headed debt recognition deed on behalf of the Act after the enactment of the Judicial Power Law, from 1970 until now, the Head of the deed said his words changed to justice based on the One Godhead, by being given the order (Head of the Deed), the purpose of the debt recognition deed has executorial power, can be executed as well as the decision of a judge who has permanent legal force. The execution of a debt recognition deed can be carried out by the court, without going through a civil court proceeding.

The reality that occurred in the District Court of class I A Mataram regarding the existence of Grosse Deed of Debt recognition based on the results of the author's interview with the Deputy Chairperson of the PN. Mataram (Suradi, SH., S.Sos.) Has given an authority which basically says that even though the Grosse debt recognition certificate has been recognized by law and is able to provide security to the creditor as the owner of the money but the creditor never applies or make a Grosse debt recognition certificate as determined or regulated in the Act. That the creditor or the general public in practice does a lot of legal actions by making an agreement on the recognition of ordinary debt made before a Notary in the head of the Deed not made for the sake of justice based on the One God, so that it 
clearly has no executorial power and extends the chain to resolve the problem that occurred so forced to file a civil suit at the District Court.

The same thing was also said by notary Ermi Purnamasari, SH. M.Kn., when interviewed, the practice in the field of the community never made Grosse a debt acknowledgment deed with the ruling on the head of the deed which sounded for justice based on the One Godhead, because the community or credit parties who come to the notary's office have mutual trust and goodwill so that the debt recognition agreement made without the means for justice based on the Almighty Godhead has been seen as sufficient to secure itself as a creditor and be felt both by creditors and debtor. Thus, it can be said that the practice in the field as a Notary for 15 years has never made a Grosse certificate of debt recognition as specified in the Act of Notary position that has executive powers, without going through a process of suing the District Court.

Furthermore, based on the results of interviews with Senior Advocates Karmal Maksudi, SH., In Law Office 108 (Former Chairperson of the DPC PERadi Mataram-NTB) at Perumnas said that practices that often occur in the field for the time being have no clients asking for help to make Debt Recognition Deed in a Notary with the head of the Deed that is said for justice based on the Supreme Godhead, it is caused by an incomprehension of the client in understanding the meaning of the Debt Recognition Deed and most of his clients who request assistance to make a debt agreement and even ask for a debt recognition deed with a guarantee in the Notary. His client has felt protected because in the debt recognition deed made in the Notary is published or also stated about the object of guarantee when the debtor does not fulfill the performance as the content or material contained in the debt recognition deed.

\section{B. Obstacles in Grosse Execution of Debt Recognition Deeds in the Class 1A District Court of Mataram}

Several factors that can cause obstacles in executorial grosse deeds in the court include: 1) There are differences of opinion between notaries and judges and the Supreme Court of the Republic of Indonesia regarding any deeds that can be made in executorial-style Grosse forms; 2) The strict Kuranng law that regulates the Grosse certificate is mainly in the case of Grosse debt recognition deed such as Article 224 HIR which is used as a legal basis for executing grosse deed of debt recognition. In Article 224 HIR it is only regulated in general about the Grosse deed, so that obstacles often arise in practice; 3 ) There is too narrow an interpretation of the judges and Supreme Court officials of the Republic of Indonesia on Article $224 \mathrm{HIR}$, especially on Grosse debt recognition deeds which can be carried out in court; 4) There is misuse of grosse debt recognition deeds as explained above that in practice it is not uncommon to misuse the contents of the grosse deed in the form of debt recognition.

Based on Article 224 HIR and 258 paragraph (1) RBG grosse debt recognition deed has executorial power, this is intended to protect credit if the debtor defaults in an agreement. In order for the execution of the grosse deed to be granted in an execution, a formal requirement such as: 1) Grosse deed of debt must be racy or headed for justice based on the Almighty Godhead. 2) Under Grosse the debt recognition certificate must include the words given as the first Grosse, stating the name of the person requesting it and for whom Grosse was issued and the date of the issuance. 3) Grosse debt recognition deed must be stamped or stamp stamped. Whereas the material requirements of a Grosse Debt Recognition Act are: 1) Grosse debt recognition deed in the form of unilateral recognition from the debtor; 2) Grosse debt recognition deeds must contain purely debt recognition, no other requirements must be added or confused with guarantee agreements or mortgage rights; 3) In the Grosse debt recognition deed, the amount of debt must be specified.

Based on the results of interviews with Didik Jatmiko (Public Relations of Mataram District Court) and Abdurrahim, SH. (Jury Sita Mataram), information was obtained that until now there had been no problems or obstacles in executing Grosse Debt Recognition Deed or no community had submitted an 
application execution in PN. Mataram, however, which could hinder the execution of Grosse Debt recognition deed, namely:

1. Factor of community understanding related to grosse debt recognition deed. In practice, people are often found to make Grosse ordinary debt recognition deeds because masayrakt considers that by making the recognition of dinotasris debt has been considered strong, but if there is a default made by the debtor, the ordinary debt recognition deed made at the notary, execution cannot be applied but must be by way of filing an ordinary lawsuit to the court, this of course requires a very long time, compared to the grosse of the debt recognition deed.

2. Factor of Legal Knowledge. Based on the provisions of Article 224 HIR and 258, the RBG regulates the debt acknowledgment letter that must be made in the form of an authentic deed, a debt acknowledgment that has the order for justice based on the Godhead Maha Esa has the executive power, from the article it can be known that the grosse can be made deed is solely for the recognition of debt cannot form a debt recognition agreement

3. Uncomprehension factor from the Notary himself in making the Grosse Debt recognition Deed, so the Notary felt reluctant to make Grosse Debt recognition Deed.

4. Factor of one party or both parties who do not want to make Grosse Deed of debt recognition, because the debt recognition agreement made by the dinotaris without Irah-irah for the sake of justice The Almighty has been considered sufficient to resolve the problem.

5. Stakeholder Factors.

The execution of the Grosse of the deed of debt recognition is not infrequently stopped, because of the resistance of execution carried out by the debtor or the third party with the object which is the object of the execution. Irrational actions by using all legal efforts are mainly driven by bad faith in an effort to avoid its obligation to settle its debts. In practice, debtors are often negligent in fulfilling credit loans which have been formulated in authentic deeds and the debtor's negligence appears when warned by the Court which then continues with the act of execution, the debtor proposes execution resistance.

The authority of a District court judge executes the grosse of a debt recognition deed as contained in Article 224 HIR, namely: 1) The competent judge can immediately order the execution of a notary grosse deed because the value of the power of the grosse deed is the same as the decision of a judge who has obtained permanent legal force; 2) The judge has the authority to order execution when the debtor meets the grosse deed and the creditor submits an execution request to the district court; 3) The court judge leads the way the execution order is issued. Thus the district court does not have the authority to assess the defect or not of the grosse deed and must carry out the execution of each grosse of the debt recognition deed submitted to him.

\section{Conclution}

The Strength of Grosse Debt Recognition Deed in the Implementation of Debt Payments is a very strong power that is undoubtedly existed because a request for execution can be immediately submitted to the Local District Court, the District Court Institution that Executes Debt Recognition Deed, with Deed made before the Notary Then Top The basis of the Execution Request from the Creditors, Next, the District Court executes the Execution Event as a form of execution of the Debt Recognition Deed that Has Executorial Strengths With the Guidance for Justice Based on the One Godhead. 
Grosse deed of debt recognition can be carried out directly without going through a claim process in court, considering the strength that exists in Grosse debt recognition deeds that have executorial power. a court institution, therefore with the existence of the power contained in the debt recognition deed, direct execution can be carried out by the creditor to the court if the debtor conducts a default, without going through a claim process in court.

Inhibiting Factors of Grosse Execution Execution Debt Recognition Deed as known in the Making of Grosse Debt Recognition Deed made on the Agreement of the Parties Not to resolve the Persolannya Through the District Court process, It Has Caused Opinion As if Grosse Execution Debt Recognition Certificate Is Non-Executable or Unable The execution is carried out by the court, this is different from the resolution of disputes carried out by the parties which were first carried out through court proceedings, with these conditions based on the applicable procedural law which is usually carried out by the court as a front poster in providing legal certainty for each litigants.

\section{References}

Fikri, A., A. \& Tanzah, E. 2010. Penjelasan Hukum Tentang Grosse Akta. Nasional legal Reform Program: Jakarta.

HIR (Herzien Inlandsch Reglement) dan RBG (Reglement Tot Regeling Van Het Rechtswezen In De Gewesten Buiten Java En Madura)

Husni, L. 2010. Hukum KetenagaKerjaan Indonesia. Raja Grafindo Persada: Jakarta.

Juhaya, P. S. 2011. Teori Hukum dan Aplikasinya. CV Pustaka Setia: Bandung.

Juhaya, S., P. 2011.Teori Hukum dan Aplikasinya, Pustaka Setia Bandung.

Muhammad, K., A. 2002. Hukum Perusahaan Indonesia, Cetakan Kedua Revisi. Citra Aditya Bakti: Bandung.

Mukti F. N.D. \& Yulianto A. 2010. Dualisme Penelitian Hukum Normatif \& Empiris. Pustaka Pelajar: Yogyakarta

Supramono, G. 2013. Perjanjian utang piutang. Kencana Media Group: Jakarta

Supramono, G. 2013. Perjanjian utang piutang. Kencana Media Group: Jakarta

Undang-Undang Dasar Negara Republik IndonesiaTahun 1945.

Undang-Undang No. 2 tahun 2014 perubahan Undang-Undang No. 30 tahun 2004 tentang Jabatan Notaris (Lembaran Negara Republik Indonesia Tahun 2014 Nomor 3), Tambahan Lembaran Negara Republik Indonesia Nomor 5491.

Undang-Undang No. 30 tahun 2004 tentang Jabatan Notaris (Lembaran Negara Republik Indonesia Tahun 2004 Nomor 117), Tambahan Lembaran Negara republik Indonesia Nomor 4432. 
Undang-Undang No. 4 tahun 1996 tentang Hak Tangguhan Atas Tanah beserta benda-benda yang berkaitan dengan tanah ( Lembaran Negara Republik Indonesia Tahun 1996 Nomor 42), Tambahan lembaran Negara Republik Indonesia Nomor 3632.

Undang-Undang Republik Indonesia No. 10 Tahun 1998 Tentang Perubahan Atas Undang-Undang Nomor 7 Tahun 1992 Tentang Perbankan.

\section{Copyrights}

Copyright for this article is retained by the author(s), with first publication rights granted to the journal. This is an open-access article distributed under the terms and conditions of the Creative Commons Attribution license (http://creativecommons.org/licenses/by/4.0/). 